\section{SCS124 Sardo: Brazilian rice cultivar with excellent milling quality}

\section{Rubens Marschalek ${ }^{1}$, Ester Wickert ${ }^{1}$, Klaus Konrad Scheuermann ${ }^{1}$, Laerte Reis Terres ${ }^{1}$, José Alberto Noldin ${ }^{1}$, Eduardo Rodrigues Hickel ${ }^{1}$, Marcos Lima Campos do Vale ${ }^{1}$ and Alexander de Andrade ${ }^{1^{*}}$}

\begin{abstract}
SCS124 Sardo is a medium-maturing cultivar with an upright growth habit; intermediate lodging tolerance; moderate blast resistance; high grain yield potential; and long, thin grains with excellent cooking and sensory quality, especially for white milled rice. It is suitable for parboiling and recommended for all regions of the state of Santa Catarina, Brazil.
\end{abstract}

Keywords: Oryza sativa, breeding, milled rice, breeding.

\section{INTRODUCTION}

The state of Santa Catarina is the second largest lowland rice-growing region in Brazil, where rice is planted on an area of 144,5 thousand ha, with an annual paddy rice production of $1.232,3 \mathrm{t}$ (Conab 2019). The activity generates high foreign exchange returns and plays an important socio-economic role in the state. The Agricultural Census of 2017 recorded 5,039 rice producing farms in Santa Catarina, each of which cultivates an average area of around 30 ha. In relation to the number of rice farms registered by the Agricultural Census of 2006 , the current number represents a reduction of $22.41 \%$.

The development of new cultivars with a desirable grain quality and high gain yield potential, and which are adapted to different soil and climatic regions is mandatory to maintain the rice industry of Santa Catarina. Although the already available cultivars developed by Epagri are suitable for the white milled rice market, none of these was classified as excellent for this purpose. On the other hand, almost the entire rice production of Santa Catarina is processed as parboiled rice, while the rice industries located there usually have industrial units in the state of Rio Grande do Sul to buy and mill other cultivars for the white rice market. This white milled rice production, bought by industries from farmers in Rio Grande do Sul, represents financial resources that could stay in Santa Catarina if the farmers could provide the local industry with high-quality grain. Since the reason for this evasion is apparently the better grain quality of rice cultivars grown in Rio Grande do Sul, which are more suitable for white rice, the Lowland Rice Breeding Program of Epagri developed and released cultivar SCS124 Sardo to fill this gap. This cultivar is recommended for lowland rice producers of the state of Santa Catarina and is the $32^{\text {nd }}$ rice cultivar released by Epagri and the $24^{\text {th }}$ for this state.
Crop Breeding and Applied Biotechnology 20(1): e28212017, 2020 Brazilian Society of Plant Breeding. Printed in Brazil http://dx.doi.org/10.1590/198470332020v20n1c7
*Corresponding author: E-mail: alexanderandrade@epagri.sc.gov.br (iD) ORCID: 0000-0002-1091-1356

Received: 04 July 2019 Accepted: 06 October 2019 Published: 13 February 2020

${ }^{1}$ Epagri, Estação Experimental de Itajaí, 88.318-112, Itajaí, SC, Brazil 


\section{BREEDING METHODS}

Cultivar SCS124 Sardo was derived by the pedigree method from a cross made at Epagri in 2008 (Epagri 108/// SCSBRS TioTaka//Fedearroz 50/Epagri 108)////SC 655). The resulting seeds were sown to establish the $F_{2}$ population, in which genetic variability was observed, as expected. Selection was initiated, targeting phenotypic traits of interest, e.g., growth habit, plant height, grain yield, grain type, number of grains per panicle and panicle type. Agronomical traits such as grain yield were evaluated, starting from $F_{3}$ families. The selected plants ( $F_{3}$ progenies) in turn originated the $\mathrm{F}_{4}$ generation. Seeds of the plants selected in the $\mathrm{F}_{4}$ generation formed the lines tested in the "preliminary trial", in the $F_{5}$ generation. In these phases, the populations were grown based on technical recommendations of Epagri for lowland rice production (Eberhardt and Schiocchet 2015). The occurrence of rice blast (Magnaporthe oryzae) and other diseases was carefully registered. In the $\mathrm{F}_{6}$ generation (2014/2015), the new inbred line was named SC 836 and evaluated again for grain yield potential, lodging tolerance, plant height, tolerance to iron toxicity, blast resistance and grain quality (Marschalek et al. 2008). Moreover, line SC 836 was included in VCU (Value for Cultivation and Use) trials in two seasons (2016/2017 and 2017/2018), at three locations (Itajaí, Turvo and Mirim Doce, SC, Brazil). Statistical analyses were carried out with software GENES and the Scott-Knott test at 5\% (Cruz 2006). Based on the performance in the VCU trials, line SC 836 was released in 2019 as SCS124 Sardo. The name of the cultivar is a tribute to several rural workers, members of the family Sardo, who have been and are still working since many years at the Experimental Station of Itajaí (EEI) of the Agricultural Research and Rural Extension Company of Santa Catarina (Epagri).

\section{PERFORMANCE CHARACTERISTICS}

The morphological and agronomic traits of cultivar SCS124 Sardo are listed in Table 1. The evaluations were mainly based on the Handbook of Research Methods in Rice (Embrapa 1977) and rules and forms of the Brazilian Ministry of Agriculture, Livestock and Food Supply (Mapa) for DHS (distinguishability, homogeneity and stability evaluations) (Mapa 2008). Cultivar SCS124 Sardo has a modern upright growth habit, medium-maturing cycle of 134 days (for comparison: cv. Epagri 106 - 125 days, cv. SCS116 Satoru - 159 days), good tillering capacity and

Table 1. Morphological and agronomic traits of cv. SCS124 Sardo in VCU* and DHS** (Mapa) evaluations (2016/17 and 2017/18)

\begin{tabular}{|c|c|c|}
\hline Plant trait/descriptor & & 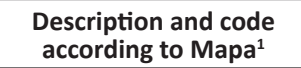 \\
\hline Leaf color & $* *$ & Green (2) \\
\hline Leaf pubescence & $* *$ & Medium (5) \\
\hline Auricle color & $* *$ & Green (1) \\
\hline Ligule color & $* *$ & Green or colorless ( 1 ) \\
\hline Flag leaf angle & $* *$ & Upright (1) \\
\hline Plant height (stem length) & $*$ & $76.7 \mathrm{~cm}$ \\
\hline Stem width & $* *$ & $5.3 \mathrm{~mm}$ \\
\hline Tillering angle & $* *$ & Upright (1) \\
\hline Internode color & $* *$ & Light Green (1) \\
\hline Anthocyanin pigmentation in node & $* *$ & Absent/Weak (1) \\
\hline Panicle length & $* *$ & $25.4 \mathrm{~cm}$ \\
\hline Type of panicle & $* *$ & Intermediate (3) \\
\hline Panicle exsertion & $* *$ & Medium (3) \\
\hline Shattering & $* *$ & Difficult (5) \\
\hline Awns & $* *$ & Absent $(0)$ \\
\hline Awn length & $* *$ & ------ (1) \\
\hline Stigma color & $* *$ & White (1) \\
\hline Lemma/palea pubescence & $* *$ & Medium (5) \\
\hline Keel color (flowering) & $* *$ & Green (2) \\
\hline Keel color (maturing) & $* *$ & Yellow (2) \\
\hline Glume (lemma and palea) color & $* *$ & Golden/straw (1) \\
\hline Sterile lemma color (glumes) & $* *$ & Straw (1) \\
\hline Cycle to maturity & $*$ & Medium (134 days) \\
\hline \multicolumn{3}{|l|}{ Disease resistance: } \\
\hline Leaf blast & $*$ & Moderately resistant (5) \\
\hline Panicle blast & $*$ & Moderately resistat (5) \\
\hline Iron toxicity tolerance ${ }^{2}$ & $* * *$ & Moderately suscetible (6) \\
\hline Tillering & $*$ & Intermediate \\
\hline Lodging & $*$ & Intermediate tolerance \\
\hline
\end{tabular}

${ }^{1}$ Mapa (Brazilian Ministry of Agriculture, Livestock and Food Supply - Mapa 2008); ${ }^{2}$ SES/IRRI (Standard Evaluation System) (IRRI 2013); * VCU trials (Itajaí, Turvo and Mirim Doce), in 2016/17 and 2017/18; ** DHS - distinguishability, homogeneity, stability (Mapa) evaluations $2016 / 17$ to $2017 / 18$; *** Iron Toxicity Field Trial.

Table 2. Average grain yield ( $\mathrm{kg} \mathrm{ha}^{-1}$ ) of SCS124 Sardo, Epagri 106, and SCS116 Satoru, in VCU trials (Itajaí, Turvo and Mirim Doce), in $2016 / 2017$ and $2017 / 2018$ growing seasons

\begin{tabular}{|c|c|c|c|c|c|c|c|}
\hline \multirow[t]{2}{*}{ Cultivar } & \multicolumn{2}{|c|}{ Itajaí } & \multicolumn{2}{|c|}{ Turvo } & \multicolumn{2}{|c|}{ Mirim Doce } & \multirow[t]{2}{*}{ Average } \\
\hline & 2016-17 & 2017-18 & 2016-17 & 2017-18 & 2016-17 & 2017-18 & \\
\hline SCS124 Sardo & 8,467 & 9,124 & 9,924 & 9,096 & 7,879 & 8,036 & $8,754 \mathrm{~b}$ \\
\hline Epagri 106 & 8,039 & 10,101 & 7,935 & 8,460 & 7,405 & 7,879 & $8,267 \mathrm{~b}$ \\
\hline SCS116 Satoru² & 10,643 & 10,673 & 10,620 & 10,625 & 9,687 & 7,689 & 9,989 a \\
\hline
\end{tabular}

${ }^{1}$ Means with different letters differed significantly by the Scott Knott test at 5\% (ANAVA by software GENES/UFV with CV 19.28\%); ${ }^{2}$ Higher-yielding long-cycle cultivar. 
upright and hairy leaves. The cultivar is more lodging-tolerant than Epagri 106. Preharvest grain loss of the cultivar as well as iron toxicity tolerance and blast disease resistance are intermediate. In the VCU trials in Itajaí, Turvo and Mirim Doce (SC-Brazil), the medium-maturing cultivar SCS124 Sardo produced a mean yield of 8,754 $\mathrm{kg} \mathrm{ha}^{-1}$, similar to the mean yield $\left(8,267 \mathrm{~kg} \mathrm{ha}^{-1}\right)$ of the early-maturing control cultivar Epagri 106 (Table 2).

Cultivar SCS124 Sardo has long, thin and translucent grain (Figure 1), with a low percentage of chalky grain and chalky grain surface area and a high and stable milling quality of $67.4 \%$ for white milled rice (Table 3 ), which are desirable traits for a recommendation as white milled rice. A $100 \mathrm{~g}$ sample of raw rice, dehulled and milled with a laboratory Rice Mill (Suzuki MT.08) of the Lamgen (Rice Breeding Laboratory - Epagri - Experimental Station Itajaí), was used for the physical grain analysis. The milled rice samples were then analyzed by the Image Rice Grain Scanner/SelgronEpagri (Marschalek et al. 2017) (Table 3). Cooking and sensory tests of a rice sample of SCS124 Sardo (SC 836) of the 2016/2017 growing season, after a storage time of three months (equalization time), attested the high quality of the cultivar (Table 4). This test confirmed that the grains were preserved loose, with soft texture, good aroma, and good taste. The line was evaluated as the best of 64 Epagri rice lines. Cooking and sensory tests were performed as defined by ABNT (1998) norms (Analysis number RA-025,

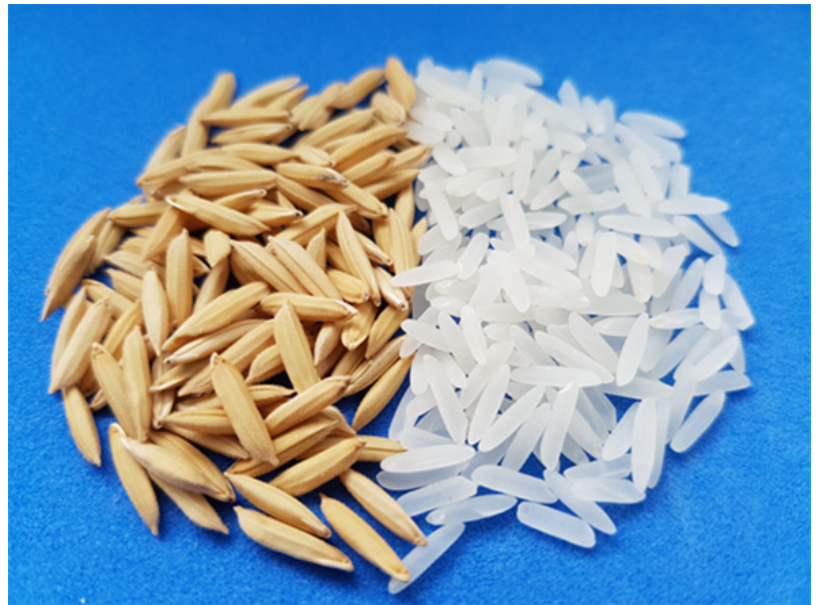

Figure 1. Paddy and milled rice grains of cv. SCS124 Sardo.

Table 3. Grain traits of cultivar SCS124 Sardo in VCU trials (2016/17 and 2017/18 growing seasons)

\begin{tabular}{|c|c|c|c|}
\hline \multirow{2}{*}{ Traits } & \multicolumn{3}{|c|}{ Cultivar } \\
\hline & SCS124 Sardo & Epagri 106 & SCS116 Satoru \\
\hline Total milled grain $(\%)^{* * *}$ & 67.4 & 67.8 & 65.1 \\
\hline Whole grain $(\%)^{* * *}$ & 61.8 & 62.1 & 58.6 \\
\hline Broken grain $(\%)^{* * *}$ & 5.6 & 5.7 & 6.6 \\
\hline Amylose content (\%) & $25.23^{*}$ & $23.9^{\bullet}$ & $25.5^{\bullet}$ \\
\hline Gelatilization temperature** & 6.7 (low) & 2.8 & 2.8 \\
\hline Chalky grain $(\%)^{* * *}$ & 5,4 & 7.6 & 7.3 \\
\hline Grain length $(\mathrm{mm})^{* * *}$ & 7.22 & 6.90 & 7.15 \\
\hline Grain width $(\mathrm{mm})^{* * *}$ & 1.99 & 2.16 & 2.20 \\
\hline Grain thickness $(\mathrm{mm})^{* * *}$ & 1.68 & 1.72 & 1.72 \\
\hline Length: width ratio*** & 3.63 & 3.19 & 3.25 \\
\hline
\end{tabular}

* Labgrãos/UFPel (McGrane et al. 1998); • Embrapa/CNPAF (International Standard Method ISO 6647, 2007); ** Embrapa/CNPAF (Martinez and Cuevas 1989); *** Traits analyzed by Image Rice Grain Scanner (Selgron-Epagri) at Lamgen (Rice Breeding; Laboratory - Epagri - Experimental Station Itajaí), except for 1000-grain weight (only Lamgen).

Table 4. Sensory grain traits in the $2016 / 2017$ growing season of some of the 64 lines tested at the quality laboratory

\begin{tabular}{|c|c|c|c|c|c|c|c|}
\hline Cultivars & $\begin{array}{l}\text { Characte- } \\
\text { ristic odor }\end{array}$ & $\begin{array}{l}\text { Strange } \\
\text { odor }\end{array}$ & $\begin{array}{c}\text { Grain labil- } \\
\text { ity }\end{array}$ & Color & Text. & $\begin{array}{l}\text { Characte- } \\
\text { ristic taste }\end{array}$ & $\begin{array}{c}\text { Strange } \\
\text { taste }\end{array}$ \\
\hline SCS124 Sardo * & 0.90 & 1.40 & 0.70 & 0.20 & 0.60 & 0.60 & 0.40 \\
\hline Epagri 106 & 3.55 & 1.70 & 3.80 & 1.55 & 4.75 & 1.15 & 1.10 \\
\hline SCS116 Satoru & 2.55 & 2.8 & 2.5 & 1.1 & 4.8 & 0.95 & 1.25 \\
\hline Epagri 109 & 0.90 & 1.30 & 2.00 & 0.40 & 0.80 & 0.50 & 0.40 \\
\hline Mean of 64 lines (2016/2017 growing season) & 1.69 & 1.50 & 2.57 & 1.17 & 2.42 & 1.49 & 1.61 \\
\hline
\end{tabular}

Scale varies from 0 (best value) to 5 (worst value) according to ABNT NBR14140 (1998). Analyses by company Urbano Agroindustrial;

* Classification of the grain quality laboratory Urbano Agroindustrial: "very good (best of the 64 samples)". 
July 2017, according to ABNT NBR 14140) by the grain quality laboratory of the company Urbano Agroindustrial.

The grains of cv. SCS124 Sardo are also suited for parboiled rice. Based on the laboratorial analysis, the hydration time of the parboiling process should not be longer than 4.5 hours (270 minutes), at temperatures not exceeding $65^{\circ} \mathrm{C}$, followed by autoclaving for $12 \mathrm{~min}$ (Figure 2) (Technical report, certificate number 21, 23/5/2018, Labgrãos/UFPel). Therefore, since the results indicate that SCS124 Sardo is different from other Epagri cultivars in the parboiling process, it is recommended to process the grains of SCS124 Sardo separately or to blend them with cultivars with a similar parboiling pattern, i.e., requiring a lower temperature and less time for parboiling.

Due to the excellent agronomic traits and outstanding industrial performance and sensory traits for white milled and parboiled rice, this cultivar is recommended for cultivation and industry in all rice-producing areas in the state of Santa Catarina.

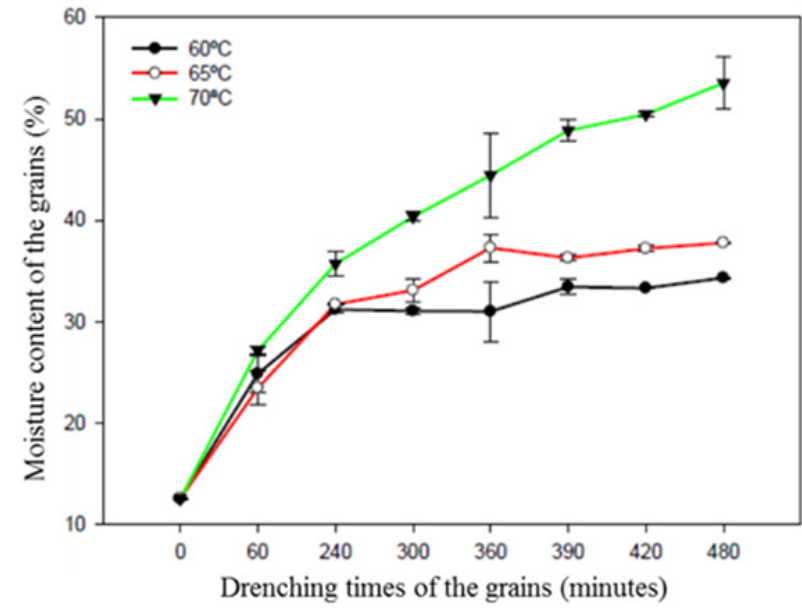

Figure 2. Hydration curves of grain and standard deviation of cv. SCS124 Sardo (Technical report, certificate number 21, 23/5/2018, Labgrãos/UFPel).

\section{FOUNDATION SEED PRODUCTION}

SCS124 Sardo is recognized by the Brazilian Ministry of Agriculture, Livestock and Food Supply (Mapa) under registration number 39426 (09/25/2018), and the provisory protection number is 20190013 (4/1/2019). Genetic seed stock is maintained by Epagri, at the Experimental Station Itajaí, Rodovia Antônio Heil, n.6800, Itaipava, CEP 88318-112, Itajaí, SC, Brazil. Certified seed of cultivar SCS124 Sardo is produced by the Association of Irrigated Rice Seed Producers of Santa Catarina (Acapsa) and will be available for sowing on commercial rice fields in the growing seasons of 2019/2020.

\section{ACKNOWLEDGEMENTS}

The National Council for Scientific and Technological Development (CNPq), Santa Catarina Research Foundation (Fapesc), and the Brazilian Innovation and Research Funding Agency (Finep) supported the development of this technology financially. The authors are also grateful to the Association of Irrigated Rice Seed Producers of Santa Catarina (Acapsa), the Syndicate of Rice Industries in the State of Santa Catarina (Sindarroz-SC), Brazilian Agricultural Research Corporation (Embrapa Rice and Beans) and Urbano Agroindustrial.

\section{REFERENCES}

ABNT (1998) NBR14140 Sensory analysis - methodology - quantitative descriptive analysis (QDA) - food - beverage. Available at <https:// www.abntcatalogo.com.br/norma.aspx?ID=004432>. Accessed on July 04, 2019.

Conab - Companhia Nacional de Abastecimento (2019) Acompanhamento da safra brasileira de grãos. Available at <https://www.conab.gov. br/info-agro/safras/graos/boletim-da-safra-de-graos>. Accessed on July 04, 2019.

Cruz CD (2006) Programa Genes - Biometria. Editora UFV, Viçosa, 382p.

Eberhardt DS and Schiocchet MA (2015) Recomendações para a produção de arroz irrigado em Santa Catarina (Sistema pré-germinado). Epagri, Florianópolis, 92p.
Embrapa (1977) Manual de métodos de pesquisa de arroz: $1^{\text {a }}$ aproximação. Embrapa Arroz e Feijão, Goiânia, 106p.

IRRI - International Rice Research Institute (2013) Standard Evaluation System (SES) for rice: $5^{\text {th }}$ edition. IRRI, Manilla, $65 \mathrm{p}$. Available at <http://www.clrri.org/ver2/uploads/SES_5th_edition.pdf $>$. Accessed on July 04, 2019.

Mapa (2008) Descritores mínimos de arroz. Available at <http://www. agricultura.gov.br/assuntos/insumos-agropecuarios/insumosagricolas/protecao-de-cultivar/arquivos-agricolas/arroz-formulario5nov1997-alterado-em-01jun2008-p.doc>. Accessed on July 04, 2019.

Marschalek R, Silva MC, Santos SB, Manke JR, Bieging C, Porto G, Wickert E and Andrade A (2017) Image - Rice Grain Scanner: a threedimensional fully automated assessment of grain size and quality 
SCS124 Sardo: Brazilian rice cultivar with excellent milling quality

traits. Crop Breeding and Applied Biotechnology 17: 89-97.

Marschalek R, Vieira J, Ishiy T, Schiocchet MA and Bacha RE (2008) Melhoramento genético de arroz irrigado em Santa Catarina. Agropecuária Catarinense 21: 54-56.

Martínez C and Cuevas F (1989) Evaluación de la calidad culinária y molinera del arroz: Guía de estúdio. Centro International de Agricultura Tropical (CIAT), Cali, 95p.

McGrane SJ, Cornell HJ and Rix CJ (1998) A simple and rapid colorimetric method for determination of amylose in starch products. StarchStärke 50: 158-163. 